\title{
VENTA DE COSA AJENA Y VENTA CELEBRADA POR MANDATARIO SIN PODER
}

\author{
SALES BY THE NON-OWNER AND SALES ENTERED \\ BY AN AGENT WITHOUT AUTHORITY
}

\begin{tabular}{|c|c|}
\hline \multicolumn{2}{|c|}{ ARTÍCULO INÉDITO DE INVESTIGACIÓN } \\
\hline CÓMO CITAR ESTE ARTÍCULO (CHICAGO) & 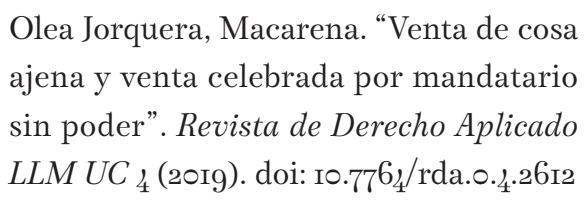 \\
\hline REVISTA DE DERECHO APLICADO LLM UC & $\begin{array}{l}\text { Número } 4 \\
\text { Diciembre } 2019 \\
\text { ISsN: } 245^{2-4344}\end{array}$ \\
\hline & $\begin{array}{l}\text { Recepción: } 2 \text { de septiembre, } 2019 \\
\text { Aceptación: } 9 \text { de diciembre, } 2019\end{array}$ \\
\hline
\end{tabular}




\section{Resumen}

La actuación de un mandatario sin poder - esto es, que nunca tuvo poder-, que se extralimitó de las facultades que se le concedieron, que dicho poder expiró, o que es nulo, produce una serie de problemas. En este artículo analizaremos la relación que existe entre el mandato sin poder y la regla del artículo 1.815 del Código Civil, que dispone la validez de la venta de cosa ajena, sin perjuicio de los derechos del propietario.

Palabras clave: Mandato, compraventa de cosa ajena, representación, extralimitación, nulidad.

\section{Abstract}

An agent acting without authority because he never was an agent, or acting beyond the authority granted by the principal, or due to the termination of the agency, or because the agency relationship is null and void, produces several problems. In this work we will analyze the relationship between an agent acting without authority with the statutory rule of article 1,815 of the Civil Code, that states the validity of the sales by the non-owner, without prejudice of the rights of the truly owner.

Keywords: Agency, sales by the non-owner, agent's authority, lack of authority, nullity. 


\section{Macarena Olea Jorquera}

Universidad de los Andes

Santiago, Chile

maolea1@miuandes.cl

Universidad de los Andes

Santiago, Chile

maolea1@miuandes.cl
Macarena Olea Jorquera es abogada, licenciada en Ciencias Jurídicas y Sociales de la Universidad de Chile. Es profesora instructora en la Universidad Finis Terrae y en la Universidad Mayor, Chile. Es autora de "Cómputo de plazo de prescripción y naturaleza de la obligación del mandatario: Comentario a la sentencia de Corte Suprema, rol 1738-2015”, publicado en Gaceta Jurídica 435; y coautora de "Las garantías en el derecho de familia”, en Estudios sobre garantías reales y personales, tomo 2 (Jurídica de Chile, 2009), 723-733. En la actualidad es alumna regular del programa de Doctorado en Derecho de la Universidad de los Andes, Chile.

Macarena Olea Jorquera, lawyer admitted on 2009, JD Universidad de Chile Law School. Professor of contracts, torts and property at Universidad Finis Terrae and Universidad Mayor, Chile. She wrote "Cómputo de plazo de prescripción y naturaleza de la obligación del mandatario: Comentario a la sentencia de Corte Suprema, rol 1738-2015" (How to count the period of the statute of limitations and the nature of the obligation of the agent: comment to the judgment of Supreme Court, case 1738-2015), Gaceta Jurídica 435. She is also coauthor of "Las garantías en el derecho de familia" (Suretyships on Family Law), at Estudios sobre garantías reales y personales, Volume 2 (Editorial Jurídica de Chile, 2009), 723733. She is currently student of the Doctorate Program on Law at Universidad de Los Andes, Chile. 


\section{PLANTEAMiento}

Entre las cuestiones que plantea la actuación de un mandatario que por diversas razones no tiene poder para representar al mandante, un punto que no ha sido en gran medida desarrollado por nuestra doctrina es la aplicación a estos casos de la regla del artículo 1.815 del Código Civil, que dispone la validez de la venta de cosa ajena, sin perjuicio de los derechos del propietario.

Un ejemplo puede ilustrar el problema: haciéndose pasar por mandatario de Diego, Juan vende un automóvil a Pedro. El automóvil es de propiedad de Diego, que no ha manifestado su voluntad de venderlo. Para determinar los efectos del contrato de venta, surge el problema de si estamos frente a un supuesto de venta de cosa ajena y, por tanto, el contrato es válido pero inoponible a Diego, al tenor del artículo 1.815 del Código Civil, o si se trata de un contrato celebrado por un mandatario que no tenía facultades para representar a Diego, caso en el cual podrían aplicarse los artículos 2.154, 2.160 y 2.173 del Código Civil, dependiendo de cada caso, lo que podría significar que el mismo contrato de compraventa fuera nulo por falta de consentimiento o que sea válido y produzca efectos oponibles al dueño-mandante, por aplicación de las normas protectoras de terceros.

La mayor parte de la doctrina considera, aunque sin muchas argumentaciones, que en estas situaciones estamos ante una venta de cosa ajena. Alessandri Rodríguez sostiene que hay compraventa de cosa ajena si el mandatario obra fuera de los límites de su mandato, o si el gerente de una sociedad anónima vende un bien social sin estar facultado para ello, ya que al extralimitarse obran por su propia cuenta y venden lo ajeno ${ }^{1}$.

En el mismo sentido, Carmona señala que "habrá, por ejemplo, venta de cosa ajena, cuando el vendedor venda una cosa que no le pertenece, sea que la venda como propia o como ajena, y esto último sucederá precisamente cuando el que vende lo hace como mandatario o representante legal del dueño sin serlo" ${ }^{2}$. Por su parte, Díez Duarte indica que uno de los casos de compraventa de cosa ajena se da precisamente cuando un mandatario se extralimita en sus facultades: "Si el mandatario se extralimita en su mandato, obra por su propia cuenta. Por tanto, si vende una cosa de su mandante sin tener facultad especial o general para celebrar esa compraventa, vende lo ajeno" ${ }^{3}$.

1 Arturo Alessandri Rodríguez, De la compraventa y de la promesa de venta. Tomo I, volumen I (Santiago: Jurídica de Chile, 2003), 237.

2 Juan de Dios Carmona Peralta, La confirmación y la ratificación de los actos jurídicos (Santiago: Nascimento, I943), $9^{8}$.

3 Raúl Díez Duarte, La compraventa (Santiago: El Jurista, 2009), 373. 
Encontramos opiniones en contrario: Íñigo de la Maza y Ricardo Torres, al analizar la situación de la compraventa de cosa ajena, sostienen que no procede aplicar el artículo 1.815 del Código Civil, ya que "los casos que han sido señalados como de falta de voluntad por mandatos falsificados o revocados se encuadran fuera del campo operativo del artículo 1.815, a cubierto del tratamiento que prodiga la regulación del mandato para supuestos de falsus procurator" ${ }^{4}$. Se fundan en que el vendedor de la cosa ajena actúa a su nombre y por cuenta propia, lo que no ocurre en los casos de mandatario sin poder.

En varios fallos los tribunales superiores han aplicado la regla de la venta de cosa ajena a casos de mandato sin poder, pues dan por sentado que este contrato es inoponible al mandante, en tanto dueño de la cosa ${ }^{5}$. Así, la Corte de Santiago ha resuelto que

la inoponibilidad es el efecto jurídico anejo tanto a la venta de cosa ajena, como a todo otro acto o contrato ejecutado por quien carecía de mandato o representación legal de la persona a quien trató de obligar. Por ello es por lo que la inoponibilidad es inseparable de la acción de dominio cuanto esta se funda en un acto o contrato respecto del cual no opera la modalidad de la representación” ${ }^{6}$.

En otros casos, en cambio, la Corte Suprema aplica las reglas del mandato y no las de la venta de cosa ajena: declara la nulidad de la compraventa por falta de consentimiento del

4 Íñigo de la Maza Gazmuri y Ricardo Torres, "Incumplimiento del vendedor: Estudios y sentencias". Revista Chilena de Derecho $4^{2}, \mathrm{n}^{\circ}{ }^{\circ} 3$ (20I5): $785^{-8 \mathrm{I} 8}$.

5 Corte Suprema, rol 24967-20I4, 3 de junio de 20I5. En el mismo sentido: Corte Suprema, rol I48 846-20I3, 23 de marzo de 20I5; Corte Suprema, rol I41 8 -2006, $2_{4}$ de marzo de 2008.

6 Corte de Apelaciones de Santiago, R.D.J.T. 62, 2. ${ }^{a}$ sección, 5 de marzo de i964, pp. 53-72. Se trata de una acción reivindicatoria interpuesta por el Banco Alemán Transatlántico en contra del Banco del Estado de Chile. Este último adquirió un bien raíz ubicado en Valdivia, que era de propiedad del Banco Alemán, el 9 de marzo de i945. Se inscribió el inmueble a nombre de la Caja Nacional de Ahorros (antecesora del Banco del Estado de Chile) producto de una escritura pública de compraventa celebrada por el Superintendente de Bancos como vendedor, el que, sin embargo, carecía de representación legal, y no se encontraba autorizado por el Banco Alemán para vender y transferir el inmueble. En primera instancia, el Tercer Juzgado de Letras en lo Civil de mayor cuantía de Santiago acogió la demanda de nulidad absoluta del contrato de compraventa por falta de consentimiento, y ordenó la restitución del inmueble. La Corte de Apelaciones de Santiago revocó el fallo, no dando lugar a la acción de nulidad, ya que el acto es inoponible, por lo que accedió a la acción reivindicatoria y por este motivo ordenó la restitución del inmueble. 
mandante "si es un hecho del pleito que en el mandato [...] no se dio expresamente la facultad de vender, la declaración de nulidad de una venta sin poder para ello se imponía”

En este trabajo demostraremos que la venta de cosa ajena y la venta celebrada a partir de un mandato sin poder son dos instituciones jurídicas diferentes. La principal consecuencia de esto es que la venta de cosa ajena es un contrato válido, mientras que la venta celebrada a partir de un mandato sin poder no lo es. Para fundamentar lo anterior, analizaremos en primer lugar la simple venta de cosa ajena, luego estudiaremos el mandato sin poder, y por último abordaremos las diferencias entre la compraventa de cosa ajena y la compraventa celebrada por un mandatario sin poder.

\section{VENTA DE COSA AJENA}

\section{I. Validez de la compraventa}

La venta de cosa ajena es un contrato válidamente celebrado, que produce efectos entre las partes. Sin embargo, al no pertenecer la cosa al vendedor, la tradición no transfiere el dominio porque el tradente no es dueño. En este caso se aplica lo previsto por el artículo 1.815 del Código Civil, es decir, la compraventa es válida sin perjuicio de los derechos del verdadero dueño de la cosa, mientras no se extingan por el tiempo transcurrido. En la práctica, esto significa que, si la cosa ha sido entregada al comprador, el dueño puede recuperarla ejerciendo la acción propia del dominio: la reivindicatoria, frente a la cual el comprador solo podría alegar la prescripción adquisitiva ordinaria o extraordinaria. Respecto de las partes, el contrato es plenamente válido, y constituye un justo título para poseer.

\subsection{Situación del dueño de la cosa}

Si se vende una cosa ajena, pero no se puede hacer la entrega material porque la cosa vendida está en posesión del dueño, el tercero comprador carecerá de una acción en contra del dueño de la cosa, porque las acciones de que dispone emanan del contrato, y el dueño no es parte en él. Por esta razón, si el comprador intentara alguna acción contra el dueño, este último se defendería alegando la inoponibilidad del contrato de compraventa (artículo 1.815).

7 Corte Suprema, R.D.J. T. I9, sección I. ${ }^{a}$, I6 de octubre de i920, pp. 406-409. Las señoras Juana Rosa, Carmen y Rufina Deudariena demandaron a Camilo Guzmán solicitando se declarara nula una compraventa de una casa de su propiedad, ya que - según los términos de su mandato general- Guzmán no estaba autorizado a vender. El Primer Juzgado de Letras de Concepción acogió la acción de nulidad, porque al contrato de compraventa le faltó el consentimiento. La sentencia fue confirmada por la Corte de Apelaciones de Concepción, y presentado recurso de casación en el fondo en contra de la sentencia, este fue rechazado. 
Otra situación posible es que se venda una cosa ajena, y el vendedor efectúe la tradición al comprador porque la cosa se hallaba en su poder. En este caso, el propietario de la cosa vendida tiene la acción reivindicatoria contemplada en los artículos 889 y siguientes del Código Civil.

La acción reivindicatoria deberá entablarla el dueño en contra del comprador, que es el actual poseedor. En esa situación deberemos aplicar las reglas de las prestaciones mutuas que se encuentran a partir del artículo 904 del Código Civil.

Por último, no debemos olvidar que el verdadero dueño de la cosa puede ratificar el contrato de compraventa y la tradición, lo que queda a su arbitrio. Si ratifica, el contrato le afecta porque pasa a asumir la calidad de vendedor desde la fecha del contrato, según lo dispuesto en el artículo 1.818 del Código Civil. Respecto de la tradición, los efectos se retrotraen a la fecha de ella, como lo dispone el artículo 673 del Código Civil.

\subsection{Situación del vendedor}

El vendedor va a ser responsable respecto del comprador y también del verdadero dueño de la cosa, pero a distinto título.

Respecto del comprador, el vendedor debe cumplir con sus obligaciones. Surge entonces la interrogante de cuál es la principal obligación del vendedor: efectuar la entrega de la cosa y asegurar su posesión tranquila y pacífica, o transferir el dominio.

Para Alessandri, el vendedor cumple con la obligación entregando la cosa y dándole su posesión legal y material al comprador: "Por esta obligación el vendedor no se obliga a transferir el dominio de la cosa al comprador, sino únicamente a darle su posesión legal

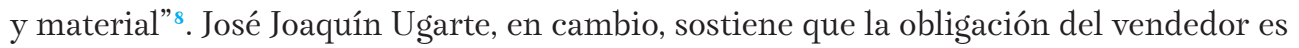
transferir el dominio. Para ello se basa en una serie de artículos del Código Civil, entre ellos el 1.793, 703, 706 y 1.824, en concordancia con los artículos de la tradición y con el 1.575, y por el artículo $1.837^{9}$.

8 Alessandri Rodríguez, De la compraventa, 662. En el mismo sentido plantea Meza Barros: "Carece el comprador del derecho para pedir la resolución del contrato, pretextando que el vendedor no le ha hecho dueño de la cosa”. Ramón Meza Barros, Manual de derecho civil: De las fuentes de las obligaciones. Tomo I (Santiago: Jurídica de Chile, 2004), $5^{8}$.

9 "Nos incumbe ahora demostrar que la obligación esencial del vendedor en el derecho chileno es transferir el dominio de la cosa y no, como se dice de ordinario, otorgar la posesión tranquila y pacífica solamente". José Joaquín Ugarte Godoy, “La obligación esencial del vendedor es transferir el dominio”. En La compraventa: Nuevas perspectivas doctrinarias, ed. por Ian Henríquez (Santiago: Thomson Reuters, 2015), 43-106; "puede afirmarse que la venta de cosa ajena no necesariamente configura un caso de incumplimiento contractual; o, para decirlo de otra manera, que el solo hecho de la existencia de un derecho de dominio de terceros sobre la cosa vendida, no necesariamente configura un supuesto de hecho de una falta de conformidad jurídica. Lo será cuando las partes hayan pactado la transferencia de dominio o, si se acepta la función integradora de la buena fe a este respecto, cuando este principio general del derecho, a falta de pacto expreso, así lo exija”. Íñigo de la Maza Gazmuri y Juan Pablo Aburto, "Falta de conformidad jurídica y tutela del comprador". Ius et Praxis 2I, n. ${ }^{\circ} 2$ (20I5): 6I-IO8. 
Determinar cuál es la obligación del vendedor no es banal, porque de ella depende si el comprador puede o no solicitar la resolución del contrato de compraventa por la sola entrega de un bien ajeno, o si por el contrario habremos de limitarnos a aplicar las reglas sobre el saneamiento de la evicción.

Si la obligación del vendedor es transferir el dominio, entonces en la compraventa de cosa ajena el vendedor está incumpliendo su obligación, lo que facultará al comprador para solicitar o el cumplimiento forzado de la obligación o su resolución, en ambos casos con indemnización de los perjuicios. Si utilizamos el artículo 1.489 del Código Civil, el comprador tiene derecho a entablar la acción resolutoria y a solicitar el resarcimiento de los perjuicios correspondientes, lo que a nuestro juicio satisface de mejor manera los intereses del comprador.

Por el contrario, si la obligación del vendedor es entregar la cosa, debe responder por el saneamiento de la evicción que establece el artículo 1.837 del Código Civil. Entonces el que vende una cosa ajena cumple su obligación entregando la cosa, pero queda sujeto a las acciones de la obligación de sanear la evicción.

En el evento de que exista evicción de la cosa vendida, el vendedor, según lo prescrito en el artículo 1.847, deberá restituir al comprador el precio de la cosa, y responder por las costas legales del contrato de compraventa, por los frutos que el comprador hubiere sido obligado a restituir al dueño, por las costas que hubiere sufrido el comprador a consecuencia de la demanda y también del aumento de valor que la cosa evicta haya adquirido en poder del comprador, ya sea por causas naturales o por el mero transcurso del tiempo.

En el evento de que el vendedor actúe de mala fe, esto es, que la vendió a sabiendas de que la cosa es ajena, cabría la reparación de todo daño extrapatrimonial ${ }^{10}$.

En virtud del artículo 1.852 del Código Civil, si el comprador había renunciado al saneamiento de la evicción, de todas formas, el vendedor va a tener que restituir el precio recibido.

En síntesis, el vendedor deberá responder al comprador ya sea restituyéndole el precio de la compraventa, asumiendo la defensa en un juicio reivindicatorio o reparándole los perjuicios que le haya ocasionado la celebración de la compraventa. Si luego el comprador es turbado en la posesión, puede citar de evicción al vendedor, como lo establece el artículo 1.837 del Código Civil.

10 Marcelo Barrientos Zamorano, "Efectos del saneamiento de la evicción”. En La compraventa: Estudios, ed. por Juan Contardo e Íñigo de la Maza Gazmuri (Santiago: Thomson Reuters, 20I7), 393 . 
Respecto del verdadero dueño de la cosa, siempre que el vendedor fue poseedor de la cosa y la enajenó, debe responder, según artículo 898 del Código Civil, en dos supuestos: cuando se ha hecho imposible o difícil la persecución de la cosa, y cuando el vendedor ha enajenado la cosa a sabiendas de que era ajena. El vendedor deberá restituir lo recibido en virtud de la compraventa, en el primer caso, o indemnizar al verdadero dueño de la cosa todo perjuicio que le haya causado, en el segundo.

\subsection{Situación del comprador}

Debemos partir de la premisa de que el contrato de compraventa es válido, pero la tradición no produjo el efecto de transferir el dominio.

El vendedor que no es dueño de la cosa no puede transferir el dominio. A pesar de ello, si hace la entrega de la cosa, deja al comprador con la posesión de la cosa vendida. La compraventa es un contrato válido que constituye un justo título, que le permite a este adquirir por prescripción adquisitiva ordinaria si está de por medio la buena fe y se hace la tradición. Ello según lo dispuesto en el artículo 1.815, relacionado con los artículos 702 y 2.507 del Código Civil.

Como mencionamos antes, el verdadero dueño de la cosa puede entablar una acción reivindicatoria en contra del comprador y este tendrá que restituirle la cosa al verdadero dueño, además de eventualmente pagar por los deterioros y los frutos de la cosa. Bajo este supuesto se produce la evicción de la cosa y el vendedor tendrá que responder ante el comprador.

El comprador, con todo, puede adquirir el dominio de la cosa por la ratificación que de la tradición hace el dueño de la cosa, según el artículo 673 del Código Civil, o porque el vendedor adquiere luego su propiedad, situación contemplada en el artículo 1.819 del Código Civil. Se reputará dueño en ambos casos, desde la fecha de la tradición.

\section{VENTA DE MANDATARIO SIN PODER}

\section{I. Tipología del mandato sin poder}

Para que se produzcan los efectos de la representación, es necesario que la persona que actúe como representante de otra actúe contemplatio domini ${ }^{11}$, y además que el representante actúe con un poder de representación ${ }^{12}$.

11 En este sentido, siguiendo a Gordillo: "La contemplatio domini hace patente al tercero que el acto no es celebrado por la persona que lo concluye, sino por otro sujeto, hecho presente en el mismo por obra de aquella”. Antonio Gordillo, La representación aparente (Sevilla: Editorial Universidad de Sevilla, 20I5), 54

12 En este sentido, siguiendo a Gordillo: "El poder de representación va a significar tanto como la particular condición de legitimidad del acto del representante que hace posible, tanto la relevancia del mismo, no obstante recaer sobre esfera jurídica ajena, como su incidencia en esta, a pesar de que no sea producto de la actividad de su titular. La actuación del representante, legitimada por el poder de representación, va a convertirse así en cauce de válidos y eficaces actos de disposición sobre la esfera del dominus, realizados, aunque no por este, sí en su nombre e interés”. Gordillo, La representación, 47 . 
Para efectos de este trabajo de investigación, nos concentraremos en las actuaciones de un representante sin cumplir con el segundo de los requisitos. Vamos a denominar mandato sin poder a aquellos casos en que una persona actúa como representante de otra sin tener para ello poder de representación o con un poder que es insuficiente, en alguno de los siguientes casos: i) cuando no hay ninguna conexión o relación jurídica entre representante y representado; ii) existe mandato, pero el representante se ha excedido de lo encargado o querido por el representado; iii) el mandato que originó el poder expiró; o iv) el mandato de donde emana el poder es nulo. El denominador común en estos cuatro casos es la inexistencia de poder. Los englobaremos todos bajo la nomenclatura mandatario sin poder $^{13}$.

Podemos preguntarnos si en cada caso se produce el mismo efecto, o si se producen diferentes efectos. Se discute si debemos distinguir entre todos los casos de mandato sin poder. En doctrina extranjera, algunos autores sostienen que no es necesario, debido a que siempre se produciría el mismo efecto ${ }^{14}$. Otros se inclinan por distinguir entre las hipótesis de mandato sin poder, dado que los efectos pueden ser diferentes. Por ejemplo, si el mandato es nulo, puede haber una agencia oficiosa ${ }^{15}$.

En nuestro país, Stitchkin ${ }^{16}$ y Alessandri ${ }^{17}$ consideran que no es necesario hacer la distinción entre los casos existentes de mandato sin poder, ya que todas las situaciones se generan precisamente porque no hay representación y los actos ejecutados por el mandatario son válidos, pero no obligan al mandante, salvo que este los ratifique.

13 Debemos recordar que la opinión dominante en nuestra doctrina es que el poder y el mandato en nuestro país son cuestiones diferentes. Stitchkin explica que no se pueden confundir el poder y el mandato, por cuanto el primero es un acto jurídico unilateral, mientras que el segundo es un contrato. Véase David Stitchkin Branover, El mandato (Santiago: Jurídica de Chile, 2009), 29 .

14 En este sentido, Werner Flume, El negocio jurídico (Madrid: Fundación Cultural del Notariado, I992).

15 Francisco Rivero Hernández, "Responsabilidad del falsus procurator por no ratificación del contrato celebrado sin poder". Anuario de Derecho Civil 59, n. ${ }^{\circ} 3$ (2006): I.०20-I.02I; Francesco Messineo, Doctrina general del contrato. Tomo I (Buenos Aires: Ediciones Jurídicas Europa-América, I986), 265-266.

16 David Stitchkin señala: "El mandatario que contrata excediendo sus poderes, o después de expirado el mandato, o sin haber tenido jamás esa calidad, actúa sin poder suficiente y sus actos son válidos, pero no obligan al mandante, salvo que este los ratifique”. Stitchkin Branover, El mandato, 367 .

17 Arturo Alessandri Besa, La nulidad y la rescisión en el derecho civil chileno. Tomo I (Santiago: Jurídica de Chile, 200I). 
Carmona, en cambio, distingue diferentes supuestos de mandato sin poder. Aunque sostiene que la sanción aplicable por regla general es la inoponibilidad, efectúa la distinción reconociendo que en algunos casos el mandante debe responder, ya sea porque se genera una agencia oficiosa o porque existe ratificación ${ }^{18}$.

Si se revisan los fallos de la Corte Suprema, estimamos que pueden distinguirse dos grupos de sentencias. En el primero hay fallos que no distinguen entre cada uno de los diferentes supuestos de mandato sin poder. Se refieren sin distinción a situaciones en que existe mandato, pero el mandatario se extralimita en las facultades que se le han concedido en virtud de este, y a aquellos casos en que una persona actúa como mandatario en circunstancias de que su mandato expiró ${ }^{19}$.

En el segundo grupo, hallamos sentencias de la Corte Suprema que establecen que, en casos de falso procurador - por ejemplo, cuando se falsificó la firma del mandante en el contrato de mandato-, se configura una infracción al numeral 2 del artículo 1.445

18 Carmona, La confirmación, I05-125.

19 Corte Suprema, rol I48 $846-203_{3}, 23$ de marzo de 20I5, considerando io. Sentencia de reemplazo, que no distingue la situación por la cual el mandato no produce efecto. El caso es el siguiente: en el año r965, Luz Eugenia Fuenzalida Vadillo contrajo matrimonio con Max Joseph Koeck Poe, quien otorgó mandato general a José Miguel Fuenzalida Comas para que administrara los bienes de Luz Eugenia Fuenzalida. En I98I el matrimonio fue declarado nulo. En I992, José Miguel Fuenzalida, en representación de su hija Luz Eugenia Fuenzalida, según mandato otorgado el $2_{4}$ de noviembre de $i_{9} 6_{5}$, vende la nuda propiedad de un inmueble perteneciente a ella, quien deduce acción de inexistencia, nulidad e inoponibilidad respecto de la compraventa y además solicita la reivindicación del bien. En el mismo sentido, Corte Suprema, rol $3^{80} 3^{\circ-}$ 2017, 6 de agosto de 2018, considerando 6. El caso es el siguiente: Phillip Amiot e Isabel Muñoz constituyeron una sociedad de responsabilidad limitada, Vicenza Limitada, el 6 de marzo del año 2006. El 20 de mayo de 2009, Isabel Muñoz otorgó un mandato amplio a Phillip para actuar en su nombre en la sociedad, cuya vigencia se condicionó a la duración de la sociedad. El mandato fue revocado en octubre de 2009 y el I3 de mayo de 2010 Isabel Muñoz manifestó su intención de ponerle término a la sociedad al final del período de vigencia a través de una escritura pública. El 9 de marzo de 2012 se celebró un contrato de compraventa entre la sociedad Vicenza Limitada, representada por Philip Amiot, que vendía un inmueble al mismo Philip Amiot. Isabel Muñoz solicitó la declaración de nulidad absoluta del contrato de compraventa, solicitud acogida en primera instancia, confirmada por la Corte de Apelaciones y contra la que se dedujo recurso de casación en el fondo que fue rechazado por la Corte Suprema. 
del Código Civil, lo que se traduce en falta de voluntad y, por tanto, la compraventa es nula de nulidad absoluta ${ }^{20}$.

A partir de lo expuesto, llegamos a la conclusión de que no siempre se producen los mismos efectos en los distintos casos de mandato sin poder, por lo que distinguiremos entre: i) falso procurador; ii) mandatario que actúa con un mandato expirado; iii) mandatario que actúa con un mandato nulo; y iv) mandatario que se extralimita en sus atribuciones.

\section{I.I. Falso procurador}

El término falsus procurator se originó en el derecho romano. Para Guzmán Brito, la contraposición verus y falsus procurator viene de los juristas clásicos, los cuales entendían al falso procurador como aquel "que simula la calidad de un tal administrador sin serlo en realidad, de modo de no actuar verdaderamente en interés del dominus, sino para defraudar a terceros en beneficio suyo" ${ }^{21}$.

20 Corte Suprema, rol I809-20I5, ro de noviembre de 20I5. El caso es el siguiente: Valentín Waintrub inició una demanda solicitando se declarara nula de nulidad absoluta la compraventa de un inmueble celebrada entre Alejandro Olivares - quien actuaba en representación de Valentín Waintrub - con Pilar Pérez el 27 de septiembre de 20ıo. El demandante solicitaba la nulidad debido a que el mandato con el que actuaba Alejandro Olivares en su representación era falso. El tribunal de primera instancia acogió la solicitud y declaró la nulidad, la Corte de Apelaciones revocó el fallo, se presentó recurso de casación en la forma y en el fondo, recurso acogido por la Corte Suprema. Según indica el considerando ro: "Que, por otro lado, cabe precisar que la situación que se ha suscitado en autos es distinta de la de aquellos casos en que esta Corte ha determinado la sanción de inoponibilidad por falta de concurrencia o consentimiento. En efecto, dicho instituto tiene lugar 'cuando se trata de actos que ejecuta una persona a nombre de otra, de quien es su representante legal o mandatario' y no tiene por objeto atacar el acto mismo sino sus efectos, dejándolo subsistir, importando solo una ineficacia. En cambio, en la especie no se trata de actuaciones que impliquen un atentado a un mandato que fue otorgado y que devinieron en inoponibles para sus otorgantes por atribución excesiva de facultades o extinción de plazos que determinaban su vigencia - pues, como se ha dicho- en este caso no existió mandato ni representación, sino una actuación de fraude, lo cual determina que el acto impugnado se encuentre afectado en su origen por vicios de tal entidad como la falta de consentimiento cuya omisión, como se ha dicho, es sancionada con la nulidad del mismo". En el mismo sentido, Corte Suprema, rol 9432-20I2, 26 de agosto de 20I3; Corte de Apelaciones de Concepción, rol i6o6-2010, i9 de mayo de 2orI.

21 Alejandro Guzmán Brito, Derecho privado romano (Santiago: Thomson Reuters, 20I3), 238. 
En la actualidad, los autores hacen sinónimos al falso procurador y al mandatario sin poder $^{22}$. Nosotros creemos que no corresponde hacerlos sinónimos, porque el falso procurador es una especie dentro del género mandato sin poder. Para efectos de este trabajo, entenderemos al falso procurador como al que simula la calidad de mandatario sin serlo ni haberlo sido.

La característica del falso procurador es que no hay contrato de mandato, solo una persona que dice ser mandataria de otra. El representado nunca manifestó su voluntad para que el falso procurador lo representara.

\section{I.2. Mandatario que actúa con un mandato expirado}

En este caso, el mandante manifestó su voluntad para que el contrato de mandato se perfeccionara, pero el contrato dejó de estar vigente. Las causales de término del mandato las encontramos contempladas de forma expresa en el artículo $2.163^{23}$, lo que no impide la aplicación de las reglas generales de término de contrato, toda vez que la naturaleza del contrato lo permita ${ }^{24}$.

Dentro de los efectos de la terminación del mandato, encontramos en primer lugar que genera nuevos derechos y obligaciones entre mandante y mandatario, como por ejemplo el pago de la remuneración convenida y la rendición de cuentas; pero el que más nos interesa es que "desde el momento mismo en que deja de existir el contrato, no será posible al mandatario ejecutar o celebrar actos válidos frente a su mandante y a terceros" ${ }^{25}$.

22 Luis Díez-Picazo, La representación en el derecho privado (Madrid: Civitas, I979), 2I;; Fernando Hinestrosa, La representación (Bogotá: Editorial Universidad Externado de Colombia, 2008), 392; Francisco Rivero Hernández, Representación sin poder y ratificación (Navarra: Civitas, 20I3), 45 .

23 El artículo 2.I63 del Código Civil establece: "El mandato termina: I) por el desempeño del negocio para que fue constituido; 2) por la expiración del término o por el evento de la condición prefijados para la terminación del mandato; 3) por la revocación del mandante; 4) por la renuncia del mandatario; 5) por la muerte del mandante o mandatario; 6) por tener la calidad de deudor en un procedimiento concursal de liquidación, el mandante o el mandatario; 7) por la interdicción de uno o del otro; 8) derogado; 9) por la cesación de las funciones del mandante, si el mandato ha sido dado en ejercicio de ellas".

24 Stitchkin Branover, El mandato, 457.

25 Hugo Gálvez Gajardo, "De la terminación del mandato" (tesis para optar al grado de Licenciado en Ciencias Jurídicas y Sociales, Pontificia Universidad Católica de Chile, I946), I2. 


\section{I.3. Mandatario que actúa con un mandato nulo}

Por las reglas generales de la nulidad, el mandato va a producir todos sus efectos mientras no haya una sentencia judicial que decrete su nulidad. Declarada la nulidad, tenemos que distinguir si se cumplieron o no las obligaciones. Si se cumplieron las obligaciones, las partes deben volver al estado en que se encontraban antes de la celebración del contrato y se aplicarán las reglas de las prestaciones mutuas; respecto de terceros, el acto ejecutado o el contrato celebrado por el mandatario va a ser inoponible al mandante. Si las partes no cumplieron con sus obligaciones, entonces el contrato se extingue. En este caso el mandante sí manifestó su voluntad, pero esta se encontraba viciada.

\section{I.4. Mandatario que se extralimita en sus atribuciones}

El mandatario solo tiene las atribuciones que su mandante le otorga en el contrato. Habrá extralimitación entonces cada vez que el mandatario actúe fuera de estas.

Según el artículo 2.131 del Código Civil, "el mandatario se ceñirá rigurosamente a los términos del mandato, fuera de los casos en que las leyes le autoricen para obrar de otro modo". Para Escudero, esta obligación "es tan categórica que constituye la principal de todas las que contrae el mandatario" ${ }^{26}$, por lo que toda vez que el mandatario se extralimita está infringiendo su obligación. Podemos llegar a la misma conclusión en caso de cumplimiento parcial del encargo, porque el mandatario tampoco se ciñe a los términos del mandato.

Stitchkin explica que los casos en los que las leyes autorizan al mandatario de un mandato civil para actuar fuera de sus atribuciones son los siguientes: i) mandatario que se encuentra en la necesidad de apartarse de los términos del mandato para obtener el objeto del mismo, contemplada en el artículo 2.134 del Código Civil; ii) caso en que puede hacer el negocio con mayor beneficio o menor gravamen, establecido en el artículo 2.147 del Código Civil; iii) mandatario que no está en situación de poder consultar al mandante, que encontramos en el artículo 2.148 del Código Civil; y iv) caso en que no fuere posible al mandatario obrar con arreglo a sus instrucciones, conforme al artículo 2.150 del Código Civil ${ }^{27}$.

En la extralimitación de atribuciones por parte del mandatario, hay contrato de mandato, el mandante manifestó su voluntad y el contrato se encuentra vigente.

26 Eduardo Escudero Heresmann, "Extralimitación y violación del mandato" (tesis para optar al grado de Licenciado en Ciencias Jurídicas y Sociales, Universidad de Chile, I947), 27.

27 Stitchkin Branover, El mandato, 275-277. 


\subsection{Cuestiones generales}

\subsection{I. ¿Puede extenderse la aplicación del artículo 2.173 del Código Civil a otros su- puestos que el mandato expirado?}

El artículo 2.173 del Código Civil establece que el mandante resulta obligado a pesar de que el mandato haya expirado. En su inciso primero prescribe: "En general, todas las veces que el mandato expira por una causa ignorada del mandatario, lo que este haya hecho en ejecución del mandato será válido y dará derecho a terceros de buena fe contra el mandante”.

En nuestra doctrina existen diferentes interpretaciones respecto de este inciso. Una interpretación sostiene la aplicación general de la teoría de la apariencia ${ }^{28}$, es decir, cada vez que hay buena fe de parte del mandatario y del tercero, la actuación del mandatario sin poder que cuenta con un poder aparente va a vincular al mandante ${ }^{29}$. En este mismo sentido opina Avelino León Hurtado ${ }^{30}$. Sirve de sustento a esta tesis, el tenor literal del artículo en su inciso primero al señalar: "En general [...]". Stitchkin, por su parte, sostiene que a pesar de que nuestro Código Civil no consagra el principio en un texto expreso, "la regla debe aceptarse en términos absolutos", debido a que "el artículo 2.173 establece la validez de los actos ejecutados por un exmandatario cuando los terceros han podido creer fundadamente que subsistían los poderes de aquél. Con mayor razón debemos reconocer la eficacia de los actos ejecutados por un mandatario cuyos poderes subsisten" ${ }^{31}$.

28 En este punto, consideramos necesario explicar los efectos de la teoría de la apariencia. Daniel Peñailillo los indica: "En cuanto a los efectos, el fundamental es que los terceros de buena fe que se han guiado por lo aparente y que, normalmente, aplicadas las reglas jurídicas pertinentes y la lógica respectiva nada habrían obtenido, adquieren efectivamente los derechos que creyeron adquirir del aparente titular. Según ya se ha dicho, no lo adquieren ni del verdadero titular ni del titular aparente (transferirlos el primero no ha querido y el segundo no ha podido), sino que, con apoyo en la noción de apariencia, de la ley”. Daniel Peñailillo Arévalo, Obligaciones: Teoría general y clasificaciones. La resolución por incumplimiento (Santiago: Jurídica de Chile, 2003), 60.

29 Heriberto Pinto Argandoña, "Los poderes aparentes" (memoria para optar al grado de Licenciado en Derecho de la Universidad de Chile, $194 \mathrm{I}$ ), 67.

30 Avelino León hurtado, La voluntad y la capacidad en los actos jurídicos (Santiago: Jurídica de Chile, r990), 256. El autor sostiene que el valor de los poderes aparentes frente a los terceros de buena fe no solo debe aplicarse en la situación prevista en el artículo 2.I73, sino que debe extenderse a todos los demás casos de poderes aparentes frente a terceros de buena fe.

31 Stitchkin Branover, El mandato, 380. 
Para quienes sostienen la aplicación general de la teoría de la apariencia, su campo de aplicación no solo abarca los casos de expiración del mandato, sino también los casos de extralimitación del mandatario.

Otra interpretación estima que la teoría de la apariencia solo se puede aplicar en cuanto haya una norma expresa que la contemple, porque es una excepción a la regla general por la cual el mandante no responde, de modo que el artículo debe ser interpretado de manera restrictiva, ya que se trata de situaciones excepcionales. Por ello se debe limitar su aplicación solo a la extinción del mandato, sin extenderla a los casos en que hay extralimitación ${ }^{32}$. No es culpa del mandante que los terceros sean negligentes en el examen de los poderes, o hayan confiado en el mandatario o incluso que hayan obrado a sabiendas de la extralimitación en que se estaba incurriendo. ${ }^{33}$

En este mismo sentido, siguiendo a Hupka, no cabe exigir al representado que haga honor a una confianza que no él, sino otro ha creado falsamente. En cambio, si el principal mismo dio a conocer al exterior el poder, debe ser mantenido a favor de ese tercero ${ }^{34}$.

Por nuestra parte, creemos peligroso ampliar la aplicación de la teoría de la apariencia, ya que estaríamos aceptando que se obligue a personas que no han manifestado su voluntad, situación excepcional que debe tener fundamento en la ley y que debe ser interpretada de manera restrictiva.

Stitchkin, por su parte, establece que para que el mandante "quede obligado por los actos del mandatario que extralimitó sus poderes, es menester que los terceros hayan incurrido en un "justo error de hecho'" ${ }_{35}$. Es decir, que el motivo que los llevó a creer que el mandatario tenía el poder suficiente para la celebración del contrato, no sea imputable a su negligencia.

En este sentido, y aplicando el artículo 2.173, una sentencia de la Corte de Apelaciones de La Serena rechazó la solicitud de nulidad absoluta por falta de consentimiento en una cesión de derechos, en la que el cedente - representado por un mandatario- había fallecido antes de la fecha de celebración del contrato. La Corte fundamentó su decisión en el

32 María José Prieto Mallett, "La protección de los terceros: El mandato aparente”. En El Mandato: Ensayos doctrinarios y comentarios de jurisprudencia, ed. por Ian Henríquez Herrera (Santiago: Thomson Reuters, 20I3), $3^{\mathrm{I}} 5^{2}$.

33 Escudero Heresmann, "Extralimitación”, 86.

34 Josef Hupka, La representación voluntaria en los negocios jurídicos (Buenos Aires: Olejnik, 20I8), 273 .

35 Stitchkin Branover, El mandato, $3^{82}$. 
hecho de que el mandatario se enteró de la muerte del mandante con la notificación de la demanda, y por tanto, que a la fecha de la ejecución del acto desconocía la expiración del mandato ${ }^{36}$.

Por último, encontramos en el inciso final del artículo 2.173 del Código Civil una contraexcepción, en virtud de la cual el mandante no deberá responder, ya que faculta al juez para absolver en su prudencia al mandante, cuando la expiración hubiere sido notificada por periódicos y en todos los casos en que no pareciere probable la ignorancia del tercero. Pensemos por ejemplo en una anotación de revocación de mandato en el Registro de Comercio $^{37}$.

\subsection{2. ¿Es aplicable el artículo 2.I54 a todos los supuestos de mandato sin poder?}

Para determinar si es procedente aplicar un artículo por analogía, es necesario analizar el supuesto de hecho que contempla la norma: en este caso es la extralimitación en las atribuciones del mandatario. Para que haya extralimitación, necesariamente debe existir un contrato de mandato, lo que implica que el mandante manifestó su voluntad para que surgiera el contrato.

36 Corte de Apelaciones de La Serena, 3I de julio de 2003. Considerando 5: "Que, en la especie, una de las cesiones del contrato impugnado viciaría de nulidad por haber fallecido el cedente a cuyo nombre actuaba el mandatario que realizó la cesión después de acaecida la muerte. Sin embargo, si bien el mandato termina por la muerte del mandante, en conformidad a lo prescrito en el artículo 2.I63 número 5 del Código Civil, mientras el mandatario la ignore, lo que este haya hecho en ejecución del mandato será válido y dará derecho a terceros de buena fe contra los herederos del mandante, de conformidad al artículo 2.I68, que requiere que el deceso sea conocido por el mandatario, y del artículo 2.I73 inciso primero del mismo cuerpo de leyes, que se refiere a las causales de expiración del mandato por causas ignoradas por el mandatario". Considerando 6: "Que el mandatario ha señalado su ignorancia respecto del fallecimiento de su mandante hasta el momento de ser notificado del libelo de autos, cuestión que implicaba un hecho negativo, por lo que correspondía al actor probar que dicho mandatario estaba, al celebrar el contrato, en conocimiento de la muerte del mandatario, prueba que no rindió, por lo que debe negar lugar a la nulidad pedida por falta de consentimiento".

37 Es necesario interpretar la frase "que no parezca probable la ignorancia del tercero”. Siguiendo a Gian Franco Rosso, esto significa que el juez tendrá que analizar si una persona razonablemente cuidadosa, puesta en la misma situación de los terceros, habría podido saber que el mandato había terminado. Gian Franco Rosso Elorriaga, "Efectos de los actos celebrados por un falso mandatario: Facultad del juez de absolver en su prudencia al mandante (artículo 2.I73 Inc. 3 del Código Civil)”. En Estudios de derecho civil I2, ed. por Hernán Corral y Pablo Manterola (Santiago: Thomson Reuters, 20I7). 
En el caso del mandatario que actúa con un mandato expirado y en el del mandato nulo, hubo un contrato de mandato y el mandante manifestó su voluntad. Desde este punto de vista, creemos posible aplicar por analogía el artículo 2.154 del Código Civil.

Sin embargo, en el caso del falso procurador, creemos que no es posible aplicar analógicamente la norma, porque el falso procurador es el que simula ser mandatario sin serlo ni haberlo sido, es decir, no hay un contrato de mandato ni declaración de voluntad del mandante, por lo que queda fuera del supuesto de aplicación.

\subsection{3. ¿Se aplica el artículo $70_{4}$ número 2 a todos los casos de mandatario sin poder?}

El artículo 704 del Código Civil menciona los títulos injustos para poseer. El número 2 se refiere al conferido por una persona en calidad de mandatario o representante legal de otra sin serlo. Surge la interrogante de cuál es el alcance que le podemos dar a la norma: zpodemos aplicarla tanto al falso procurador como al mandatario que se extralimita, al mandato expirado y al mandato nulo? Vodanovic lo ha entendido de esta forma ${ }^{38}$. Peñailillo coincide con su postura y la fundamenta en el hecho de que la ley no distingue ${ }^{39}$. $\mathrm{Al}$ analizar este numerando del artículo 704, además se refiere a la compraventa de cosa ajena, estableciendo que, si el vendedor actúa por sí, el título es justo por cuanto no se encuentra incluido en el número 2 del artículo 704. En cambio, si el vendedor actúa como representante del dueño, el título es injusto. La diferencia se justifica porque en la última situación el comprador debió haber examinado lo suficiente el poder del representante ${ }^{40}$.

38 "Falta la representación o el mandato no solo cuando jamás han existido, sino también cuando, a pesar de haber existido, han cesado antes del otorgamiento del título o el conferimiento de este implica extralimitación de las atribuciones del representante o el mandatario". Antonio Vodanovic Haklicka, Tratado de los derechos reales: Bienes. Tomo I (Santiago: Jurídica de Chile, $2001), 378$.

39 "No distingue la ley, de modo que el título es injusto sea que el que pasa por representante sepa que no lo es o crea serlo cuando realmente no lo es, es decir, esté de buena o de mala fe. Si alguien vende una cosa ajena, pero como propia, actuando por sí, el título es justo (no está incluido en el número 2 del artículo 704; ni tampoco en el número 3, porque el artículo i.8I5 dispone expresamente que la venta de cosa ajena es válida), en tanto que si la vende como ajena, diciéndose representante del dueño, el título es injusto. La diferencia parece justificarse porque en esta última situación el adquirente debió examinar suficientemente el poder que aduce quien le ha manifestado ser representante". Daniel Peñailillo Arévalo, Los bienes: La propiedad y otros derechos reales (Santiago: Jurídica de Chile, 2010), $35^{\circ}$.

40 Peñailillo, Los bienes, $35^{\circ}$. 


\subsection{Nulidad e inoponibilidad de la venta al mandante}

Por regla general, el contrato de compraventa celebrado por el mandatario sin poder va a ser ineficaz. Es necesario determinar entonces cuál es la sanción de que adolece el contrato, tema que no es pacífico y respecto del cual la jurisprudencia ha variado su postura. Hay argumentos para sostener que el acto es Inexistente, nulo o inoponible.

\subsection{Inexistencia o nulidad absoluta}

El acto ejecutado por un falso procurador o por un mandatario cuyo mandato ha expirado carece de un requisito de existencia del acto jurídico, la voluntad. En esta situación el acto es ineficaz por un defecto originario. En la doctrina nacional se ha discutido cuál es la sanción aplicable al caso, es decir, si la inexistencia - para otros autores, nulidad de pleno derecho- ${ }^{41}$ es una sanción reconocida por nuestro derecho ${ }^{42} \mathrm{o}$ si, por el contrario, en estas situaciones la sanción que se aplica es la nulidad absoluta ${ }^{43}$. La autora Lilián San Martin hizo un estudio más moderno respecto al tema y llega a la siguiente conclusión:

En suma, en el Código de Andrés Bello no cabe hablar de inexistencia como un tipo de ineficacia distinto de la nulidad absoluta, pues el legislador estaba consciente de la equivalencia conceptual entre los dos términos y deliberadamente decidió innovar estableciendo un plazo para el ejercicio de la acción de nulidad absoluta, excluyendo una acción meramente declarativa de nulidad o inexistencia ${ }^{42}$.

La postura de los tribunales superiores del país en cuanto a la sanción que se aplica a un acto ejecutado por un falso procurador ha sido vacilante. Encontramos fallos que sostie-

41 Hernán Corral Talciani, Curso de derecho civil: Parte general (Santiago: Thomson Reuters, 2018), 672 .

42 En este sentido, Luis Claro Solar explica: "Si la falta de alguno de los requisitos que la ley prescribe para el valor del acto o contrato produce la nulidad de este, la falta de uno de los requisitos que la ley establece como esenciales a perfeccionamiento jurídico del acto o contrato, produce su inexistencia. Esta distinción que clara y lógicamente se desprende de los propios términos del artículo r.68r, ha sido olvidada al discurrir en el concepto de que el Código al dictar reglas sobre nulidad ha empleado esta palabra para significar lo que no produce efecto, lo que no existe”. Luis Claro Solar, Explicaciones de derecho civil chileno y comparado. Volumen 6 (Santiago: Jurídica de Chile, I979), 525.

43 Arturo Alessandri Rodríguez, Manuel Somarriva y Antonio Vodanovic Haklicka. Tratado de derecho civil: Partes preliminar y general. Tomo 2 (Santiago: Jurídica de Chile, 2009), 325-326.

44 Lilián San Martin, "La teoría de la inexistencia y su falta de cabida en el Código Civil chileno". Revista Chilena de Derecho $4^{2}$, n. $^{\circ} 3$ (20I5): $745^{-7} 8_{4}$. 
nen que dicho acto adolecería de nulidad absoluta debido a que no hay voluntad ${ }^{45} \mathrm{y}$ otros en los que se establece que el acto ejecutado a partir de un mandato falso es inoponible al mandante ${ }^{26}$.

En los casos de un mandato terminado por muerte, la jurisprudencia ha resuelto que si el mandatario y el tercero que contrataron conocían la muerte del mandante, no hubo consentimiento y el acto o contrato es nulo. Pero si el mandatario y el tercero que contrata con él desconocían la muerte del mandante, el acto o contrato será válido y los herederos de este quedarán obligados por él según el artículo 2.173 del Código Civil.

En nuestra opinión, al acto ejecutado por un falso procurador o ejecutado por un mandatario cuyo mandato ha terminado por muerte le falta un elemento de existencia, en este caso la voluntad, por lo que el acto es inexistente. El problema de la nulidad absoluta es que el acto produce todos los efectos que está destinado a producir mientras el juez no declare la nulidad, lo que implicaría que la persona a cuyo nombre se celebró el acto quedaría obligada por este, lo que creemos es injusto para el mandante. Por esta razón, consideramos que lo correcto es sostener que el acto es inexistente.

45 Corte Suprema, rol I809-2015, ro de noviembre de 20I5. En el mismo sentido, Corte Suprema, rol 9432-2012, 26 de agosto de 2013 .

46 Corte de Apelaciones de Concepción, rol I606-20Io, I9 de mayo de 20rI. El caso es el siguiente: Elba Martínez solicita en lo principal se declare la nulidad absoluta tanto de un mandato supuestamente otorgado por ella a Juan Gallegos, el que carecía de voluntad, puesto que le falsificaron la firma, como de una compraventa en la que Gallegos, en su representación, vendió un terreno en la localidad de Huilquehue. En subsidio interpuso acción de simulación y de inoponibilidad. En primera instancia se rechazó la demanda en todas sus partes. La Corte de Concepción revocó una parte del fallo, dado que consideró que el mandato era nulo de nulidad absoluta; sin embargo, la compraventa era válida por tratarse de una compraventa de cosa ajena: Considerando 6: "Que la segunda alegación de la actora y apelante, en el orden planteado, está referida a la nulidad absoluta del contrato de compraventa [...] que el mismo demandado [...] premunido del indicado mandato falso [...] celebró con Eulalia Oscarina Banda Llanos, a quien le vendió dicho inmueble [...] petición que se funda en la falta de voluntad de la supuesta mandante y vendedora, o, en subsidio, por existir simulación absoluta e ilícita o, en subsidio aún, por ser inoponible a dicha parte demandante. Al respecto cabe señalar que el contrato de compraventa indicado no adolece de ningún vicio de nulidad absoluta en atención a que la falta de un mandato verdadero [...] no es motivo para invalidar dicho acto jurídico, ya que se cumplieron todos los requisitos legales para su celebración y validez, por lo que dicho acto jurídico es plenamente eficaz entre los contratantes nombrados, ya que la venta de cosa ajena es válida sin perjuicio que resulte ser 'en principio' inoponible respecto de la dueña [...] conforme a lo que dispone el artículo r.8I5 del Código Civil”. 


\subsubsection{El caso de la nulidad prevista en el artículo 2.I27 del Código Civil}

El artículo 2.127 del Código Civil regula la situación en que existen dos o más mandatarios, y el mandante les ha prohibido obrar de manera separada. Este artículo dispone que si uno de los mandatarios actúa de forma separada, los actos y contratos que celebre en representación del mandante - por ejemplo, una compraventa— serán nulos.

En este caso, a nuestro juicio, la nulidad a que se refiere el artículo es nulidad relativa, por cuanto se establece respecto de la calidad o estado de la persona que suscribe el contrato, calidad que consiste en ser un mandatario que está obligado a actuar de manera conjunta con otros, de modo que la declaración de nulidad solo la podrá pedir el mandante.

\subsubsection{Inoponibilidad al mandante}

En los casos en que el acto es ejecutado por un mandatario que se ha extralimitado en sus atribuciones, los autores nacionales están de acuerdo en que ese acto es inoponible respecto del mandante, sobre la base de los artículos 2.154 y 2.160 del Código Civil ${ }^{4 \pi}$.

En cambio, la postura de los tribunales sobre el acto ejecutado por un mandatario que se ha extralimitado ha evolucionado. En fallos bastante antiguos, la Corte Suprema consideró que la sanción aplicable era la nulidad por falta de consentimiento del mandante. Una sentencia de 1920 resolvió la nulidad de un contrato de compraventa porque el mandatario no se encontraba facultado para vender ${ }^{28}$. En otro fallo, se declaró la nulidad absoluta de la compraventa por carecer el mandatario de las atribuciones para celebrar el contrato. El fallo de primera instancia declaró la nulidad del contrato de compraventa y la Corte de Apelaciones de Santiago confirmó la resolución. Se dedujo recurso de casación en el fondo contra la resolución, y la Corte Suprema lo rechazó ${ }^{49}$. En casos más recientes, la Corte

47 David Stitchkin señala: "Por regla general, como se ha visto, el mandatario no puede salirse de los términos del mandato, y si lo hace, queda responsable al mandante por los perjuicios que le irroga y no lo obliga respecto de terceros, artículos 2.I54 inciso primero y 2.160, inciso primero". Stitchkin Branover, El mandato, 277. En el mismo sentido, véase Escudero Heresmann, “Extralimitación y violación del mandato", ı23; y Alessandri Besa, La nulidad, 407.

48 Corte Suprema, R.D.J., T. I9, sec. ra, p. ${ }_{4} 06$.

49 Corte Suprema, R.D.J., T. I2, 9 de diciembre de I9I3. El caso es el siguiente: Fritz von Straaten confirió mandato el 25 de julio de I9०3 a Ambrosio Rodríguez para vender 300 hectáreas de terreno. El mandatario delegó su poder a Rafael Cornejo. En I9๑7 se revocó la delegación, pero de todos modos en igio Cornejo vendió el terreno a un tercero. Se solicitó la declaración de nulidad de la escritura de compraventa y la cancelación de las correspondientes inscripciones. El fallo de primera instancia declaró la nulidad del contrato de compraventa, y la Corte de Apelaciones de Santiago confirmó la resolución. Se dedujo recurso de casación en el fondo contra la resolución, y la Corte Suprema lo rechazó. Ver considerandos io y II. 
Suprema ha fallado que la sanción que corresponde aplicar en el caso de la extralimitación de las facultades del mandatario es la inoponibilidad, porque se cumplen los requisitos de existencia y de validez del acto jurídico celebrado por el mandatario. La manifestación de voluntad que perfecciona el acto es la del mandatario con la del tercero, pero esta no obliga al mandante, porque nadie puede quedar obligado sin manifestar su voluntad ${ }^{50}$.

En los casos de mandato nulo y de mandato extralimitado, el acto va a ser inoponible respecto del mandante, debido a que este había manifestado su voluntad. Había, entonces, un mandato, pero por el vicio de voluntad de que adolecía el acto, o por la extralimitación en el ejercicio de las atribuciones del mandatario, no operó la representación, salvo que hubiere buena fe de parte del mandatario, o que se hubiere extralimitado en sus atribuciones por una causa imperiosa, ya que en esos casos se deben aplicar las reglas de la agencia oficiosa.

50 Corte Suprema, rol 94:970-20I6, I7 de abril de 20I7. El caso es el siguiente: Interfactor S.A. dedujo demanda ejecutiva en contra de Arriendo de Maquinarias Valtrucks Ltda. cobrándole el pago de un pagaré por $\$ 278.000 .000$. La demandada opuso excepción de nulidad, basada en el hecho de que la mandataria carecía de poder para representar. En primera instancia, el Primer Juzgado Civil de Antofagasta rechazó la excepción a la ejecución, y la Corte de Apelaciones de Antofagasta confirmó el fallo. La demandada dedujo recurso de casación en el fondo y en la forma que fueron rechazados por la Corte Suprema. Considerando I3: "Por otro lado, aun cuando se considerare que el mandatario se extralimitó en sus facultades para el cometido del mandato, es una doctrina que se debe tener por pacífica que la sanción propia en un caso como el que se trata no es la nulidad del acto ejecutado, según se desprende de una serie de disposiciones del Código Civil, aplicables en la especie al mandato mercantil, entre otras, los artículos 2.I47, 2.I54, 2.160 del Código Civil, puesto que si se parte del supuesto que los actos ejecutados por el mandatario satisfacen los requisitos establecidos por la ley para su eficacia, es necesario concluir que son válidos y que no afecta en nada a esta conclusión la circunstancia que el mandatario no haya estado autorizado para ejecutarlos. Esto es así, porque el mandatario que contrata a nombre de su mandante lo representa en cuanto a los efectos del contrato que se producirán respecto del mismo, como si este los hubiera celebrado personalmente, pero el contrato se genera con la concurrencia de las voluntades del mandatario y del tercero. Por consiguiente, el mandante podrá alegar que esos actos o contratos no le afectan porque el mandatario no estaba autorizado para ejecutarlos o celebrarlos obligando su patrimonio y de ahí, pues, que en una hipótesis como la ventilada a propósito de la contienda de autos se está en presencia de actuaciones válidas, pero que eventualmente son inoponibles al mandante y, en todo caso, de acuerdo a lo que prevé el artículo 2.I54 del referido código, en la responsabilidad del mandatario por los perjuicios que pudieran irrogarse a aquel”. En el mismo sentido, Corte Suprema, rol I4 846-20I3, 23 de marzo de 20I5; Corte Suprema, rol 634I-20II, 3I de enero de 20I2; Corte Suprema, rol 9724-2009, 23 de diciembre de 20I0; Corte de Apelaciones de La Serena, rol II36-2009, 28 de mayo de 2009 . 


\section{$3 \cdot 3 \cdot 4$. Derechos del tercero comprador}

En contra del vendedor-mandatario. El falso procurador resultará obligado frente al tercero según las reglas de responsabilidad extracontractual, por haber incurrido en delito o cuasidelito. En el resto de los casos de mandatario sin poder, por regla general este no va a resultar obligado, salvo si no ha dado suficiente conocimiento de sus poderes o si se obliga personalmente, casos excepcionales contemplados en el artículo 2.154 del Código Civil ${ }^{51}$.

Si el mandatario no ha dado suficiente conocimiento de sus poderes, deberá responder por responsabilidad extracontractual, ya que el no dar suficiente conocimiento de sus poderes puede constituir un delito o un cuasidelito según si el mandatario obró con culpa o dolo. En este sentido, Tapia explica que "el representante que contrata a nombre del representado sabiendo que no tiene poderes para hacerlo, sin poner en conocimiento del tercero contratante esta situación, actúa dolosa o negligentemente y se hace responsable de un delito o cuasidelito que, de conformidad con las reglas que a los hechos ilícitos se refieren, oblíganlo a la reparación del daño causado" ${ }^{22}$.

El tercero tendrá una acción por responsabilidad extracontractual contra el mandatario para obtener el resarcimiento de los perjuicios ocasionados por el ocultamiento de los poderes durante las negociaciones entre el mandatario y el tercero, según lo dispuesto en el artículo 2.154, en relación con los artículos 2.314 y 2.329 del Código Civil. Estos perjui-

51 Encontramos otras reglas que se refieren a un representante que actúa fuera de sus atribuciones. El artículo $55^{2}$ del Código Civil prescribe: "Los actos del representante de la corporación en cuanto no excedan de los límites del ministerio que se le ha confiado, son actos de la corporación; en cuanto excedan de estos límites, solo obligan personalmente al representante". A nuestro juicio, esta disposición, a pesar de que se trata de una situación similar, la soluciona de una manera totalmente distinta, porque el representante se obligará. Balmaceda hace una referencia al artículo en cuestión: "La probable justificación del artículo 552 se encuentra en que el legislador no quiso aplicar las normas del mandato a esta materia para evitar una posible confusión entre ambas instituciones. La ley considera la representación de las personas jurídicas en una posición distinta a la de un simple mandato”. Carlos Balmaceda Lazcano, El estatuto de las personas jurídicas (Santiago: Nascimento, I943), I9o. Por su parte, el artículo 2.094 del Código Civil va en un sentido similar al establecer: "El socio que contrata a su propio nombre y no en el de la sociedad, no la obliga respecto de terceros, ni aun en razón del beneficio que ella reporte del contrato; el acreedor podrá solo intentar contra la sociedad las acciones del socio deudor. Si el socio contrata a nombre de la sociedad, pero sin poder suficiente, no la obliga a terceros sino en subsidio y hasta concurrencia del beneficio que ella hubiere reportado del negocio".

52 Orlando Tapia Suárez, De la responsabilidad civil en general y de la responsabilidad delictual entre los contratantes (Santiago: Legal Publishing, 2007), 55०. 
cios en nuestra opinión deberían incluir aquellos consistentes en el menoscabo sufrido por el tercero como consecuencia de no poder exigir al mandante el cumplimiento del contrato, porque si el tercero hubiese tenido acceso a los poderes, habría podido constatar que el mandatario carecía de facultades, por lo que probablemente no habría celebrado el contrato.

Si el mandatario se ha obligado en forma personal, será parte del contrato y por esa razón naturalmente quedará obligado frente al tercero con el que contrató bajo el régimen de responsabilidad contractual. Al respecto, Stitchkin nos explica que la correcta forma de interpretar esta frase es en el sentido de que el mandatario se obliga de forma solidaria, subsidiaria o que ha prometido la ratificación del mandante, en cuyo caso estamos frente a una promesa de hecho ajeno ${ }^{53}$.

No parece que pueda caber la obligación subsidiaria, ya que si no hay obligación principal (es inoponible), no puede existir obligación accesoria. Sí procedería, en cambio, que el mandatario se obligue de manera solidaria, caso en el cual él se estaría obligando como vendedor exclusivo.

Otra figura que podría resultar aplicable a este caso es la promesa de hecho ajeno regulada en el artículo 1.450 del Código Civil. En ella la obligación que contrae el promitente es hacer de su parte todo lo necesario para obtener la ratificación del tercero y conseguir que el contrato se forme entre el tercero y el otro contratante, aunque la parte que promete el hecho de otro es garante de un compromiso, pero no de la ejecución de la obligación. Si el tercero por quien ha de darse, hacerse o no hacerse alguna cosa no ratifica la obligación, el efecto es que el promitente quedará responsable de la indemnización de los daños sufridos por el otro contratante ${ }^{54}$. En los términos del mandatario sin poder, esto significa que se compromete a que el mandante ratificará la compraventa, y si este no lo hace, el tercero comprador podrá solicitar que el mandatario le indemnice los perjuicios que esta situación le generó. Se discute si esta indemnización es por responsabilidad contractual o extracontractual.

En contra del dueño mandante. El tercero, por regla general, no podrá exigir al mandante el cumplimiento de la obligación en ninguno de los casos de mandato sin poder, dado que el mandante no es parte del acto jurídico que celebró el mandatario sin poder y no opera la representación.

Aplicando las reglas de la prescripción, el tercero puede adquirir el bien por prescripción adquisitiva extraordinaria, ya que su posesión es irregular porque viene de título injusto conforme a lo dispuesto en el artículo 704 numeral 2 del Código Civil.

53 Stitchkin Branover, El mandato, $3^{86 .}$

54 Claro Solar, Explicaciones, 435. 


\section{3·4. Validez y oponibilidad de la venta al mandante}

\subsection{Caso general}

El contrato de compraventa celebrado por el mandatario sin poder puede ser ratificado por el mandante o por sus herederos. La ratificación "es un acto jurídico unilateral, en virtud del cual una persona acepta como suyas las declaraciones de voluntad hechas en su nombre por otra que carecía de poder suficiente ${ }{ }_{55}$.

El mandante puede ratificar el contrato celebrado por el mandatario sin poder, conforme lo prescrito en el inciso segundo del artículo 2.160 del Código Civil, que dice: "Será, sin embargo, obligado el mandante si hubiere ratificado expresa o tácitamente cualesquiera obligaciones contraídas a su nombre”.

El Código Civil establece que la ratificación del mandante tiene efecto retroactivo ${ }^{56}$, por lo que, si hay ratificación, se entiende que el contrato le es oponible a partir de la fecha de su celebración.

\section{3·4.2. Nulidad de mandato y extralimitación}

El mandatario sin poder que actúa en atención a un mandato nulo y que se extralimita, si actúa de buena fe, es considerado agente oficioso, conforme a lo dispuesto en el artículo 2.122 del Código Civil y, además, puesto que el artículo 2.287 del Código Civil prescribe que las obligaciones del agente oficioso son las mismas que las del mandatario.

El artículo 2.122 establece: "El mandatario que ejecuta de buena fe un mandato nulo o que por una necesidad imperiosa sale de los límites de su mandato, se convierte en un agente oficioso". Esta disposición contiene una doble excepción a la regla conforme a la cual el mandante no responde si el mandato es nulo, pero el mandatario actuó de buena fe, y si el mandatario se extralimitó en sus atribuciones por una necesidad imperiosa. Creemos que se produce la misma situación que en la extralimitación cuando el artículo 2.161 establece que la ejecución parcial del mandato no obliga al mandante sino en cuanto le aprovechare.

En estos casos el mandatario es visto como un agente oficioso; por ende, de forma excepcional, el mandante deberá responder si la gestión le ha resultado útil, según lo dispuesto en el artículo 2.290 del Código Civil, que indica: "Si el negocio ha sido bien administrado,

55 Stitchkin Branover, El mandato, $37^{\circ}$.

56 Stitchkin señala que los artículos 672,673 , 721, I.577 y ı.8I8 del Código Civil establecen la retroactividad. Stitchkin Branover, El mandato, 373. 
cumplirá el interesado las obligaciones que el gerente ha contraído en la gestión”. Dado que la buena fe se presume, frente a un reclamo del tercero el mandante podrá defenderse probando que el mandatario actuó de mala fe o que el negocio no le resultó útil.

En estas situaciones, el mandante va a resultar obligado por la utilidad del negocio, lo que constituye un criterio objetivo ${ }^{57}$. No es necesario que el mandante ratifique el acto o contrato ${ }^{58}$.

\subsubsection{Mandatario con mandato expirado}

El artículo 2.173 del Código Civil regula específicamente la situación excepcional por la que el mandante resulta obligado, a pesar de que el mandato había expirado. Este artículo prescribe:

En general, todas las veces que el mandato expira por una causa ignorada del mandatario, lo que este haya hecho en ejecución del mandato será válido y dará derecho a terceros de buena fe contra el mandante.

Quedará asimismo obligado el mandante, como si subsistiera el mandato, a lo que el mandatario sabedor de la causa que lo haya hecho expirar, hubiere pactado con terceros de buena fe; pero tendrá derecho a que el mandatario le indemnice.

Cuando el hecho que ha dado causa a la expiración del mandato hubiere sido notificado al público por periódicos, y en todos los casos en que no pareciere probable la iǵnorancia del tercero, podrá el juez en su prudencia absolver al mandante.

En esta situación se requiere la buena fe del tercero para que el mandante resulte obligado. La buena o mala fe del mandatario determinará si él debe indemnizar o no los perjuicios que sufra el mandante por la ejecución del acto. Encontramos en el inciso final del artículo 2.173 una contraexcepción, en que el mandante no deberá responder.

Por último, debemos mencionar que estas mismas reglas se aplican en caso de que el mandante revoque el mandato, y esta situación sea desconocida por el mandatario y el tercero que contrata con él, conforme a lo dispuesto en el artículo 2.165, que prescribe: "El mandante puede revocar el mandato a su arbitrio, y la revocación, expresa o tácita, produce su efecto desde el día que el mandatario ha tenido conocimiento de ella; sin perjuicio de lo dispuesto en el artículo 2.173”.

57 Jorge López Santa María, Los contratos: Parte general (Santiago: Thomson Reuters, 20I7), 359 .

58 Claro Solar, Explicaciones, ${ }_{4} 3$. 


\subsubsection{Posibilidad del mandante de pedir responsabilidad al mandatario}

En primer lugar, si el mandante ratificó el contrato, el mandatario no necesita responder. Si el mandante no ratifica, pero de todas formas resulta obligado, el mandatario deberá responder. En el caso de falso procurador y muerte del mandante, responderá por las reglas de la responsabilidad extracontractual. En cambio, en el caso del mandatario que se extralimita en sus atribuciones o que actúa a partir de un mandato nulo, responderá por las reglas de responsabilidad contractual.

Si el falso procurador ocasiona perjuicios al supuesto mandante, deberá responder de ellos según las reglas de la responsabilidad extracontractual, dado que no hay un vínculo entre ambos.

Respecto del mandatario sin poder que se extralimita en sus atribuciones, Stitchkin distingue una serie de circunstancias. La primera es si se cumplió o no el contrato de mandato. Por ejemplo, si el mandato era para vender un inmueble y el mandatario hipoteca, deberá indemnizarle el mandatario al mandante los perjuicios provenientes del incumplimiento. Si el mandante ratifica, se entiende que renuncia a la indemnización de perjuicios. Sin embargo, en caso de experimentar perjuicios a pesar de que el acto o contrato le resulte inoponible, el mandatario deberá responder por $\operatorname{estos}^{59}$, por ejemplo, si el tercero demandó en juicio al mandante y tuvo que pagar los honorarios de un abogado.

El mandatario sin poder que se extralimita en sus atribuciones está incumpliendo el contrato de mandato, por lo que el mandante podrá solicitar una indemnización de perjuicios proveniente de la responsabilidad contractual, la que se puede fundar ya sea en el artículo 1.489 o en el artículo 1.555, ambos del Código Civil.

El mandatario sin poder que actúa en atención a un mandato expirado por muerte del mandante deberá responder ante los herederos del mandante si estos resultan obligados con terceros que contrataron de buena fe, conforme al artículo 2.173 inciso segundo del Código Civil. Creemos que esta responsabilidad es extracontractual porque tiene su origen en la ley y los hechos que la originan son posteriores al término del contrato de mandato.

\section{COMPARACIÓN ENTRE VENTA DE COSA AJENA Y VENTA CELEBRADA POR MANDATARIO SIN PODER}

\section{I. Similitudes}

Las similitudes de las situaciones son bastante evidentes, pues en ambos casos hay tres partes: un mandante-dueño, un vendedor-mandatario o no dueño, y un comprador o

59 Stitchkin Branover, El mandato, 362. 
tercero que contrata con el mandatario. Se trata de un contrato de compraventa de una cosa corporal y que ha cumplido con las solemnidades que le son propias, en conformidad con la naturaleza de la cosa vendida.

La sanción de la compraventa efectuada por alguien que no es dueño es, por regla general, la de inoponibilidad al dueño o al supuesto mandante.

A pesar de las similitudes, encontramos una serie de diferencias que analizaremos.

\subsection{Diferencias}

\subsection{Nombre bajo el que actúa el vendedor}

En la compraventa de cosa ajena, el vendedor vende como propia una cosa ajena y actúa a nombre propio; en cambio, el mandatario sin poder actúa a nombre del dueño de la cosa, y el comprador cree que está adquiriendo la cosa del verdadero dueño porque entiende que debería operar la representación.

No estamos de acuerdo en este punto con la mayoría de la doctrina, que considera que si el mandatario obra fuera de los límites de su mandato, obra por su propia cuenta y vende lo ajeno ${ }^{60}$. Precisamente el problema radica en que, aun al extralimitarse de sus facultades, el mandatario no está actuando a nombre propio, sino a nombre del mandante, situación diferente de la venta de cosa ajena, en que el vendedor actúa a su propio nombre. En este sentido parece correcta la opinión de Rivero Hernández, quien explica que, en la compraventa de cosa ajena, el vendedor actúa en su propio nombre y en su propio interés, lo que hace que el acto quede fuera de la esfera de la representación ${ }^{61}$.

60 En este sentido: Alessandri Rodríguez, De la compraventa, 237; Carmona, La confirmación, 98; y Díez Duarte, La compraventa, 373 .

61 Francisco Rivero señala: "Disposición de cosa ajena [...] me refiero en este caso al acto de persona que, en nombre propio y sin intención de representar o actuar en interés de otro, dispone de una cosa o derecho de este último. Hay que insistir, para una correcta delimitación de este supuesto, en que el disponente no actúa en interés ajeno, intencional ni formalmente - no hay siquiera representación indirecta (en nombre propio e interés ajeno)—, sino con intervención proprio nomine (no menciona para nada el nombre o identidad del dueño de la cosa o titular del derecho) e interés también propio: actúa por y para sí disponiendo de cosa o derecho ajeno. En ello reside la diferencia sustancial con la representación, incluida la representación sin poder; y sitúa el acto fuera del ámbito conceptual y funcional de la representación. De ahí que dicho acto no produzca ningún efecto por ese mecanismo jurídico”. Rivero, Representación, 274 . 
Se nos presenta el problema del mandatario que se extralimita en sus atribuciones y que se ha obligado "personalmente", pues conforme al numerando 2 del artículo 2.154 del Código Civil, correspondería entonces en este caso aplicar el artículo 1.815, ya que no operó la representación. Creemos que no corresponde aplicar el artículo 1.815 en este caso, pues aquí el mandatario no actúa a su propio nombre, sino que se obligó de manera personal a través de una promesa de hecho ajeno, lo que constituye una situación diferente.

\subsubsection{Sanción aplicable a la compraventa}

Si bien, por obra de los artículos 1.815 y 2.160 del Código Civil, la ineficacia del contrato de compraventa será la de inoponibilidad al dueño o mandante, ello no siempre será así, ya que la compraventa que celebra el falso procurador y el mandatario que actúa con un mandato expirado va a ser inexistente, al faltar un elemento de la esencia del acto jurídico, esto es la voluntad.

Aunque el artículo 674, al establecer que "para que sea válida la tradición en que intervienen mandatarios o representantes legales, se requiere además que estos obren dentro de los límites de su mandato o representación legal”, parece dar a entender que la tradición efectuada por un mandatario que se extralimita sería nula, hemos de seguir la interpretación de Vial y de Vodanovic, quienes consideran que, más allá del tenor literal, deben primar los principios generales de la representación en cuanto modalidad ${ }^{62}$. Siguiendo a estos autores, no habría una diferencia respecto de la tradición, porque el modo en que interpretan el artículo 674 permite llegar a la conclusión de que tanto el efecto de la tradición efectuada por el que no es dueño como el producido por la tradición efectuada por un mandatario que no obra dentro de los límites de su mandato o representación legal son uno y el mismo, esto es, la inoponibilidad respecto del verdadero dueño de la cosa.

\subsubsection{Obligación que genera el contrato de compraventa respecto del dueño de la cosa}

Por otra parte, al aplicar las reglas del mandato de los artículos 2.122 y 2.173, el mandante va a resultar obligado en algunas situaciones; en cambio, si aplicamos el artículo 1.815, el verdadero dueño de la cosa no va a tener obligación alguna, porque siempre le es inoponible la compraventa.

62 En este sentido, Víctor Vial sostiene: "En conclusión, la tradición hecha por un mandatario o por un representante legal que actúa a nombre del tradente o del adquirente excediendo los límites de su mandato o representación legal, no adolece de un vicio de nulidad. Lo que ocurre es que la tradición no va a producir efectos para el representado, lo que significa que no es oponible a este a menos que ratifique lo obrado por su representante”. Víctor Vial del Río, La tradición y la prescripción como modos de adquirir el dominio en el Código Civil chileno (Santiago: Ediciones UC, 2009), 63. Vodanovic Haklicka, Tratado, 203. 
Podemos preguntarnos cuál es el fundamento de esta diferencia, y es claro que en el mandato lo que se protege es la situación aparente en la que se vio involucrado el tercero que contrata; en cambio, en la compraventa de cosa ajena no se da esta situación aparente, porque el que vende siempre lo hace a nombre propio, de modo que el tercero nunca se va a ver envuelto en la situación generada por la apariencia.

El hecho de que el vendedor aparentemente sea el dueño de la cosa no obsta a la conclusión anterior, porque el comprador siempre está en condiciones de revisar los títulos de dominio en el caso de la venta, ya que suelen constar en registros públicos. Piénsese por ejemplo en la compraventa de un bien inmueble, un automóvil o acciones de una sociedad.

Sin embargo, cuando estamos frente a los poderes del mandatario, dado que el mandato por regla general no es solemne, es posible que no conste en registros públicos y que pueda ser modificado con posterioridad a su otorgamiento, evento en que el mandatario podría exhibir al tercero solo el poder original y ocultar la modificación, situación en que el tercero no estará en condiciones de poder conocer la modificación de los poderes.

\subsubsection{Naturaleza de la venta como título de posesión}

Otro aspecto en el que hallamos una diferencia entre ambas instituciones dice relación con la calidad del título que cada una de ellas genera ${ }^{63}$. Respecto de la compraventa que proviene de un mandato, el título otorgado por un mandatario sin poder no es justo aplicando la regla del artículo 704, por lo que la posesión será irregular, lo que se desprende de los artículos 702 y 708. Por tanto, solo da derecho a que el tercero adquiera el dominio del bien por prescripción adquisitiva extraordinaria de diez años, según lo prescrito en el artículo 2.510 .

En la compraventa de cosa ajena, debemos aplicar el artículo 1.815, según el cual la compraventa de cosa ajena es un título justo.

\subsubsection{Adquisición del dominio del comprador por medio de prescripción}

Por lo anterior, podemos llegar a la conclusión de que en la compraventa de cosa ajena puede adquirirse el dominio por la prescripción adquisitiva ordinaria (si hay buena fe inicial y tradición de la cosa). En cambio, en la compraventa de mandatario sin poder, la adquisición del dominio será siempre a través de la prescripción adquisitiva extraordinaria.

63 Carmona, La confirmación, Io9. 


\section{3. La cuestión en la jurisprudencia}

Encontramos algunos fallos recientes en los que se confunde el contrato de compraventa de cosa ajena y el contrato de compraventa celebrado por un mandatario sin poder. Así, la Corte de Concepción ha sostenido:

Al respecto cabe señalar que el contrato de compraventa indicado no adolece de ningún vicio de nulidad absoluta en atención a que la falta de un mandato [...] dado por la propietaria [...] no es motivo para invalidar dicho acto jurídico, ya que se cumplieron todos los requisitos legales para su celebración y validez, por lo que dicho acto jurídico es plenamente eficaz entre los contratantes nombrados, ya que la venta de cosa ajena es válida sin perjuicio que resulte ser en principio inoponible respecto de la dueña ${ }^{64}$.

No obstante, la Corte Suprema, en decisiones recientes, ha llegado a discernir la diferencia entre ambas situaciones, descartando la aplicación del artículo 1.815 a casos de ventas

hechas por mandatarios que carecen de poder para representar, en los que se distingue entre el acto ejecutado por el mandatario sin poder y la compraventa de cosa ajena. Así, por sentencia de casación dictada el 6 de agosto de 2018, la Corte sostiene:

Se equivoca el recurrente al pretender fundar su pretensión anulatoria en la situación que norma el artículo 1.815 del Código Civil, pues evidentemente no ha existido venta en el contrato cuya nulidad se demanda, ya que el demandado no compareció vendiendo una cosa ajena sino invocando una representación de la que carecía, pretendiendo aparentar la enajenación del inmueble de la sociedad de quien se decía su representante sin serlo, invocando para ello un documento aparente con el fin de adquirirla para sí $^{65}$.

Este trabajo pretende seguir y fundamentar jurídicamente esta dirección jurisprudencial, ya que refleja que no son la misma situación una compraventa de cosa ajena en la que el vendedor actúa a nombre propio, pero vendiendo una cosa ajena, que invocar un mandato que no existe, ya que en el segundo caso el vendedor que al mismo tiempo actuará como mandatario actúa a nombre del dueño de la cosa, pero sin que este haya manifestado voluntad alguna, lo que hace que el contrato de compraventa sea inexistente.

64 Corte de Apelaciones de Concepción, rol i6o6-2010.

65 Corte Suprema, rol 38.030-2017, 6 de agosto de 2018, considerando Io. En el mismo sentido, Corte Suprema, rol I809-20I5, caratulado Alejandro Olivares Gajardo como su mandatario y en calidad de vendedor, y Pilar Pérez. 


\section{CONCLUSIONES}

De nuestro análisis pueden extraerse varias conclusiones, que resumimos a continuación: La compraventa de cosa ajena y la compraventa celebrada a partir de un mandato sin poder son instituciones diferentes, ya que los efectos que se generan respecto del dueño, del vendedor y del comprador no son los mismos.

En la compraventa de cosa ajena, el que vende siempre lo hace a nombre propio; en cambio, en los casos de mandato sin poder, el mandatario actúa siempre a nombre del mandante.

La compraventa de cosa ajena es un contrato válido, que genera un título justo, en que el vendedor actúa a nombre propio y deberá cumplir con su obligación de entregar la cosa al comprador, pero esa tradición no producirá el efecto de transferir el dominio. El comprador podrá adquirir el dominio de la cosa, por regla general, por prescripción adquisitiva ordinaria y, de manera excepcional, por tradición si el dueño ratifica, única situación en la que este resultará obligado.

La situación es diferente en los casos de mandato sin poder. En ellos, a pesar de que hay o hubo un mandato, no opera la representación, ya sea porque el mandatario se extralimitó en sus facultades, porque el mandato expiró o porque era nulo. Aquí se deben distinguir las distintas situaciones: en casos de extralimitación, los actos y contratos serán inoponibles al mandante, mientras que, en casos de expiración del mandato por muerte del mandante, y los contratos celebrados por un falso procurador con terceros, serán inexistentes por falta de consentimiento.

El vendedor-mandatario actúa a nombre del dueño mandante, lo que implica que no resultará obligado a responder al comprador, quien tampoco podrá exigir al dueño mandante que cumpla con el contrato, porque este no es parte. El título que se genera es un título injusto, por lo que el comprador podría adquirir el dominio por prescripción adquisitiva extraordinaria.

La protección de terceros de buena fe induce al legislador a establecer que el mandante resulte obligado por el contrato que celebró un mandatario sin poder, ya sea porque las causales de expiración eran desconocidas para el tercero (artículo 2.173) o porque se aplica la gestión de negocios ajenos (artículo 2.122).

El vendedor que actúa por una simple compraventa de cosa ajena responde respecto del comprador, ya que el contrato es válido. En cambio, el mandatario que vende sin poder, por regla general no resultará obligado por el contrato. En caso excepcional, el mandatario sin poder debe responder por la aplicación del artículo 2.154, es decir, si ha ocultado sus poderes o si se obliga personalmente. Esta última expresión debe entenderse como si se obliga de forma solidaria o mediante una promesa de hecho ajeno. 
El comprador también va a tener diferentes derechos dependiendo de si se trata de una compraventa de cosa ajena o de una compraventa efectuada por un mandatario sin poder. Debido a que el contrato de compraventa de cosa ajena es plenamente válido, puede solicitar el cumplimiento de las obligaciones que le corresponden al vendedor. En cambio, en el contrato de compraventa celebrado a partir de un mandato sin poder, por regla general, el comprador no va a poder exigir el cumplimiento del contrato, ya que el vendedor no actúa a nombre propio, sino que a nombre del mandante y este no resultará obligado, porque el contrato no surte efectos a su respecto.

La compraventa de cosa ajena es un título justo que permite la adquisición de la cosa a través de prescripción adquisitiva ordinaria de cinco años, mientras que el mandato sin poder constituye un título injusto que solo permite adquirir la cosa a través de la prescripción adquisitiva extraordinaria de diez años.

No corresponde aplicar la regla del artículo 1.815 del Código Civil a los casos de ventas celebradas por un mandatario que carece de poder de representación, ni siquiera en el caso del artículo 2.154 numeral 2, en que el mandatario se obliga personalmente, ya que siempre estará actuando a nombre ajeno y no a nombre propio. $\square$ 


\section{BIBLIOGRAFÍA}

- Alessandri Besa, Arturo. La nulidad y la rescisión en el derecho civil chileno. Santiago: Jurídica de Chile, 2001.

- Alessandri Rodríguez, Arturo. De la compraventa y de la promesa de venta. Santiago: Jurídica de Chile, 2003.

- Alessandri Rodríguez, Arturo, Manuel Somarriva y Antonio Vodanovic. Tratado de derecho civil: Partes preliminar y general. Tomo 2. Santiago: Jurídica de Chile, 2009.

- Balmaceda Lazcano, Carlos. El estatuto de las personas jurídicas. Santiago: Nascimento, 1943.

- Barrientos Zamorano, Marcelo. "Efectos del saneamiento de la evicción”. En La compraventa: Estudios, editado por Juan Contardo e Íñigo de la Maza Gazmuri. Santiago: Thomson Reuters, 2017.

- Carmona Peralta, Juan de Dios. La confirmación y la ratificación de los actos jurídicos. Santiago: Nascimento, 1943.

- Claro Solar, Luis. Explicaciones de derecho civil chileno y comparado. Tomo 11. Santiago: Jurídica de Chile, 1979.

- Corral Talciani, Hernán. Curso de derecho civil: Parte general. Santiago: Thomson Reuters, 2018.

- De la Maza Gazmuri, Ínigo y Ricardo Torres. "Incumplimiento del vendedor: Estudios y sentencias". Revista Chilena de Derecho 42, n. $^{\circ}$ 3 (2015): 785-818.

- De la Maza Înigo, y Juan Pablo Aburto. “Falta de conformidad jurídica y tutela del comprador”. Ius et Praxis 21, n. ${ }^{\circ} 2$ (2015): 61-108.

- Díez Duarte, Raúl. La compraventa. Santiago: El Jurista, 2009.

- Díez-Picazo, Luis. La representación en el derecho privado. Madrid: Civitas, 1979.

- Escudero Heresmann, Eduardo. "Extralimitación y violación del mandato”. Tesis para optar al grado de Licenciado en Ciencias Jurídicas y Sociales. Universidad de Chile, 1947.

- Flume, Werner. El negocio jurídico. Madrid: Fundación Cultural del Notariado, 1992. 
- Gálvez Gajardo, Hugo. “De la terminación del mandato”. Tesis para optar al grado de Licenciado en Ciencias Jurídicas y Sociales. Universidad Católica, 1946.

- Gordillo, Antonio. La representación aparente. Sevilla: Editorial Universidad de Sevilla, 2015.

- Guzmán Brito, Alejandro. Derecho privado romano. Santiago: Thomson Reuters, 2013.

- Hinestrosa, Fernando. La representación. Bogotá: Editorial Universidad Externado de Colombia, 2008.

- Hupka, Josef. La representación voluntaria en los negocios jurídicos. Buenos Aires: Olejnik, 2018.

- León Hurtado, Avelino. La voluntad y la capacidad en los actos jurídicos. Santiago: Jurídica de Chile, 1990.

- López Santa María, Jorge. Los contratos: Parte general. Santiago: Thomson Reuters, 2017.

- Messineo, Francesco. Doctrina general del contrato. Buenos Aires: Ediciones Jurídicas Europa-América, 1986.

- Meza Barros, Ramón. Manual de derecho civil: De las fuentes de las obligaciones. Santiago: Jurídica de Chile, 2004.

- Peñailillo Arévalo, Daniel. Obligaciones: Teoría general y clasificaciones. La resolución por incumplimiento. Santiago: Jurídica de Chile, 2003.

- - Los bienes: La propiedad y otros derechos reales. Santiago: Jurídica de Chile, 2010.

- Pinto Argandoña, Heriberto. "Los poderes aparentes". Memoria para optar al grado de Licenciado en Derecho. Universidad de Chile, 1941.

- Prieto Mallett, María José. “La protección de los terceros: El mandato aparente". En El mandato: Ensayos doctrinarios y comentarios de jurisprudencia, editado por Ian Henríquez Herrera (pp. 31-52). Santiago: Thomson Reuters, 2013.

- Rivero Hernández, Francisco. "Responsabilidad del falsus procurator por no ratificación del contrato celebrado sin poder". Anuario de Derecho Civil 59, n. ${ }^{\circ} 3$ (2006): 1.020-1.021.

- - Representación sin poder y ratificación. Navarra: Civitas, 2013. 
- Rosso Elorriaga, Gian Franco. "Efectos de los actos celebrados por un falso mandatario: Facultad del juez de absolver en su prudencia al mandante (art. 2.173 inc. 3. del Código Civil)". En Estudios de derecho civil 12, editado por Corral, Hernán y Pablo Manterola (pp. 405-450). Santiago: Thomson Reuters, 2017.

- San Martin, Lilian. "La teoría de la inexistencia y su falta de cabida en el Código Civil chileno". Revista Chilena de Derecho 42, n. ${ }^{\circ} 3$ (2015): 745-784.

- Stitchkin, David. El mandato. Santiago: Jurídica de Chile, 2009.

- Tapia Suárez, Orlando. De la responsabilidad civil en general y de la responsabilidad delictual entre los contratantes. Santiago: Legal Publishing, 2007.

- Ugarte Godoy, José Joaquín. "La obligación esencial del vendedor es transferir el dominio". En La compraventa: Nuevas perspectivas doctrinarias, editado por Ian Henríquez Herrera (pp. 43-106). Santiago: Thomson Reuters, 2015.

- Vial del Río, Víctor. La tradición como modo de adquirir el dominio. Santiago: Ediciones UC, 1999.

- Vodanovic Haklicka, Antonio, Tratado de los derechos reales: Bienes. 6. ${ }^{a}$ edición. Santiago: Jurídica de Chile, 2001. 